\title{
O NOVO TITULAR, PROFESSOR LUIZ OLAVO BAPTISTA, PROFERE SEU DISCURSO DE POSSE
}

Professor Antonio Junqueira de Azevedo, DD. Diretor da Faculdade de Direito, Ilustre Professor e dileto Amigo Celso Lafer, Meus Colegas,

Senhores, Senhoras,

Meus Alunos,

Seguindo a tradição desta Casa - cultora delas - de que o professor recebido em sessão solene da Congregação responda à saudação que lhe fazem seus pares, assumo esta tribuna, exprimindo, desde logo, a gratidão à homenagem que é feita aos meus colegas e a mim nesta ocasião, especialmente porque se manifesta no discurso e na sempre presente generosidade de Celso Lafer cujas boas palavras como que demonstraram publicamente a amizade que nos une - e a sua bondade que faz com que veja qualidades que não tenho

De seu discurso e do orador, direi que os descreveu o poeta,

\section{claro em pensar, e claro no sentir \\ É claro no querer"}

Já se disse desta Faculdade que "nem sempre foi poética ou heróica como nem sempre foi santa" 1

Isto ocorre porque nem sempre seus alunos e professores foram poetas, heróis ou santos, tendo havido, mesmo, o avesso desses modelos, como houve os que não sendo poetas, heróis ou santos, nem seu avesso, marcaram suas vidas por outras qualidades e defeitos. Políticos, bons e maus, trabalhadores encarniçados, boêmios memoráveis, sábios estudiosos, filósofos e bon-vivants, historiadores e sambistas, bons professores e maus professores, advogados e

1. Discurso de posse de José Ignácio Botelho de Mesquita, Revista da Faculdade de Direito da USP, São Paulo, v. 71, p. 301, 1976. 
leguleios, libertários e sabujos de ditaduras, toda a galeria, enfim, dos tipos humanos passou pelas Arcadas e deixou nelas a sua marca, e muitos, na história do país. De tudo, creio, restou o fato de que os professores ensinaram tanto pelo exemplo dado pelo seu comportamento, quanto pelas suas aulas.

Com efeito, a palavra professor tem sua raiz nos vocábulos gregos phémé (palavra) e phanai (falar), daí vindo os verbos e expressões latinos fari, fatus, de onde prefari: dizer antes; confiteri, confessus: confessar; professio: declaração e, finalmente, professor: o que faz profissão de alguma doutrina, e fala, por oposição a infans - antis, o que não fala, vindo da mesma raiz.

Dessa forma, não só as palavras, mas a conduta de um professor, são a sua profissão de doutrina.

Aí, na lembrança do que será a profissão de cada um dos que assume a missão de falar, por seus gestos e palavras, às gerações de alunos da Academia, é que reside a sabedoria desta cerimônia.

E sua finalidade é chamar cada um de nós a vir reafirmar o que foi, o que é, e fazendo a confissão do que foi, fazer a profissão de continuar fiel a si mesmo, para - bem ou mal - servir à formação dos que aqui vêm estudar.

Nasci em Itu, de paisagem semeada de rochas graníticas, que o Tietê contorna sereno e ultrapassa, com decisão, no Salto. Pescando com meu avô, nas margens do rio ainda não poluído, aprendi a conhecer a água que afasta os obstáculos sem afrontá-los, contornando-os e erodindo-os para alcançar seu destino, como também aprendi entre muitas coisas, o poder da paciência e o amor à liberdade. Com meu pai, a combatividade e o dever de enfrentar os perigos e os poderosos sem medo, assim como o de respeitar e tratar, como se fossem meus superiores, aqueles que a vida colocou em posição subalterna.

São o amor à liberdade - o respeito à liberdade de meus alunos e das pessoas - e a repulsa visceral a todo totalitarismo - que me conduzem a ver no Direito um instrumento a serviço desses ideais, como deve ser o da Justiça - que tem marcado meus passos como advogado e como professor.

Por isso, a promessa de ensinar a meus alunos o respeito pela liberdade do próximo e o amor à Justiça, como fundamentos de suas ações como servidores do Direito, é a que faço, escudado na minha história. 
Minha ação como advogado, como disse, foi sempre a de afirmar a minha liberdade e bater-me pela dos outros. Voltado por vocação para o Direito Empresarial e Internacional,

\author{
porque as faturas e as cartas comerciais são o princípio \\ da história \\ E os navios que levam as mercadorias pelo mar eterno \\ são o fim \\ Ah e as viagens..."
}

durante os anos de chumbo deixei muitas vezes minha banca e minha paixão pelo Direito Comercial e Internacional, para, numa prática alheia à minha vocação e escolha, mas imposta pela minha consciência, correr na defesa dos presos por delitos de opinião, muitos deles professores e alunos desta Universidade. Recordo-o, agora, apenas para mostrar que meu amor à liberdade não foi nem é discurso teórico, mas sim prática a que me dou a despeito de qualquer dificuldade.

É esse amor à liberdade que me faz às vezes interromper uma aula com uma catilinária contra a opressão representada pelas regulamentações burocráticas, com uma veemência que muitas vezes faz sorrir meus alunos. Assim como não hesito a envolver-me em brigas por causa de pessoas injustiçadas, tomando sempre o partido dos mais fracos contra os mais fortes.

Essa manifestação de apego à liberdade e à justiça - onde as injustiças parecem-me a negativa do direito do outro a ser reconhecido como pessoa - leva-me também a uma posição de repulsa à intolerância. Contra essa ergo-me sem conseguir ser sereno.

Aí se funda um posicionamento político que cultivo desde meus tempos de estudante, mas cuja conjugação de combatividade e libertarismo fez com que jamais eu conseguisse ser o disciplinado militante de qualquer movimento ou partido. Um sentido de repulsa contra a camisa-de-força burocrática, contra os tapaolhos ideológicos, contra o gesso das opiniões normatizadas dos grupos, me fez sempre afastar-me dessa condição e, graças a isso, poder enxergar - creio - com maior clareza e lucidez os problemas. Pude, assim, participar de todos os movimentos políticos de minha geração, escapando de dogmatismos e da escravidão das disciplinas partidárias. 
Nunca pude deixar de querer - como queria como estudante - mudar o mundo. Tentei e tento fazê-lo, com a consciência de que só terei eficácia se limitar o âmbito de minha atuação. Dessa forma pude dedicar-me às atividades de minha classe como Conselheiro e Presidente da AASP, Presidente da Caixa de Assistência dos Advogados, Conselheiro Seccional e Federal dä OAB, funções em que creio ter podido deixar a marca de minha passagem, nas atitudes que tomei e nas inovações que implantei.

Aprendi com os sobes-e-desces da política, onde incursionei nos tempos da Faculdade e de recém-formado, a distinguir as amizades dos interesses, a identificar os bajuladores, adquirindo um sólido ceticismo que, desde então, retirou para mim todo o interesse pela política partidária, sem que sufocasse o ímpeto de lutar pela liberdade e pela justiça.

Foi a paixão pela justiça, creio, que me desviou da carreira diplomática - a que me endereçava a vontade de meu pai, que me fazia estudar e ler tudo o que, achava ele, pudesse servir à formação de um diplomata ao tomar conhecimento na Faculdade com as primeiras aulas de direito e com as lições de Introdução à Ciência do Direito, em que o tema eram as concepções aristotélica e tomista da Justiça.

A escolha da carreira docente deve-se, sem dúvida, ao exemplo de minha mãe, que foi professora primária como minhas tias, e de meu pai que lecionou em Itu, no Colégio São José e, depois, na Faculdade de Medicina da Universidade de São Paulo.

A matéria a que dedico meus esforços acadêmicos - e também importante parte de minha prática - com o tempo o percebi, teve que ver com essa formação e aprendizado, e com o que sou.

Não me conformaria com um direito de dogmática, pronto e acabado, arcabouço perfeito, em que nada pudesse inovar, onde minha criatividade não pudesse existir e minha liberdade se exercer.

No Direito do Comércio Internacional, como no que regula as atividades da empresa em geral, o campo é aberto para a elaboração, a autonomia da vontade é ainda uma realidade e os instrumentos novos podem surgir.

Pode-se participar da elaboração da cartografia de um mundo novo. Assim pude me atirar com alegria e felicidade ao estudo dessas matérias e pude incursionar por temas ainda inexplorados como as joint-ventures em meu 
doutorado, as transferências eletrônicas internacionais de fundos em minha livredocência; e pude refletir em minha tese de titular sobre a liberdade relativa do redator dos contratos internacionais.

Nesses trabalhos, como na vida, senti que deveria ser como o Espinosa, descrito por Machado de Assis, ${ }^{2}$

"Nas mãos a ferramenta do operário,

e na cabeça a coruscante idéia.

E enquanto o pensamento delineia

uma filosofia, o pão diário

a tua mão a labutar grangeia

e achas na independência o teu salário

E posso, assim, tentar ver no Direito um sistema, que se subdivide em subsistemas, coordenados, integrados e interligados, de modo que a querela antiga de imonistas e dualistas me pareceu ter perdido o sentido. Foi vendo que no Direito do Comércio Internacional, as normas, emanadas dos Estados tanto para produzirem efeitos internacionais como internos integravåm o mesmo sistema em que os sujeitos de direito podiam ir criando os seus modelos jurídicos ${ }^{3}$ para atender às suas necessidades, que essa convicção se esboçou.

Nessa possibilidade de criação do modelo jurídico, as idéias de justiça e de liberdade podem se afirmar no gesto diuturno do trabalhador do Direito.

É por isso que, com alegria e entusiasmo, dedico-me à advocacia e às aulas, unidas e complementares, uma atividade enriquecendo a outra, ao permitirme propor temas novos para minhas aulas, assim como novas soluções para questões que examino. É um exercício contínuo de criatividade, em que, até novas maneiras de avaliar o progresso de meus alunos e novos métodos de ensinar, comparecem ao serviço de minha aspiração de sempre, que é levá-los a pensar, adulta e maduramente, enfrentando a vida de modo independente e criativo

Pressionado pelos limites do tempo a encerrar esta manifestação, não posso fazê-lo sem o registro de gratidão aos que me ensinaram: meus pais e avós, meus professores, dentre os quais destaco Vicente Marotta Rangel - que me deu as

2. Espinosa. In: Poesias completas-Ocidentais, Rio de Janeiro, Nova Aguilar, 1986, vol. 3, p. 163.

3. V. Miguel Reale, O Direito como Experiência, São Paulo, Saraiva, 1968. 
primeiras aulas de Direito Internacional e de ética profissional e, sobretudo, um exemplo de modéstia, dedicação e seriedade como professor; aos meus amigos que sempre me corrigiram, apoiaram e deram o suporte firme de sua amizade, entre eles, todos meus colegas de escritório, de ontem e de hoje, que sempre me facultaram a maior liberdade, especialmente Eduardo e Tito, não podendo deixar de lembrar com saudade a figura austera e combativa de Lauro Celidônio. Mas sou devedor, sobretudo, aos meus alunos que me incentivam com suas perguntas, dúvidas e, principalmente, com a promessa do brilhante futuro que espero que tenham. Encerro meus agradecimentos com aquele especial e comovido à Marta $\mathrm{e}$ ao Humberto; e renovo aquele que fiz ao meu caro Celso pela amizade que me dedica e que transparece na sua saudação.

Sinto-me pronto agora - tendo lembrado, ainda que brevemente, minha trajetória e ideais - a fazer a meus alunos, meus pares e meus amigos a promessa de que procurarei dar, com minhas lições, o exemplo do que fui, do que sou e espero continuar a ser, dedicado ao trabalho e a explorar as fronteiras do Direito do Comércio Internacional, a dar asas à imaginação para resolver os problemas, a bater-me pelo que creio, sem medo nem intolerância, para que quando for velado sob as Arcadas, fiel a essa promessa, espero, possa ter sentido, como o personagem do verso de Fernando Pessoa

"Assim vivi, assim morri a vida

Calmo sob os mudos céus,

Fiel à palavra dada e à idéia tida " 